\title{
INVESTIGATION OF THE PROCESS OF BEE POLLEN COMMINUTION
}

\author{
Sergey Merzlov \\ Department of food technology and technology processing of animal products \\ Bilotserkovsky National Agrarian University \\ 8/1 Soborna sq., Bila Tserkva, Ukraine, 09117 \\ merzlov.sergiy.ua@gmail.com \\ Neonila Lomova \\ Department of food technology and technology processing of animal products \\ Bilotserkovsky National Agrarian University \\ 8/1 Soborna sq., Bila Tserkva, Ukraine, 09117 \\ snezhkoolha@gmail.com \\ Serhiy Narizhniy \\ Department of food technology and technology processing of animal products \\ Bilotserkovsky National Agrarian University \\ 8/1 Soborna sq., Bila Tserkva, Ukraine, 09117 \\ sam_nsa@bigmir.net \\ Olha Snizhko \\ Department technologies of meat, fish and marine products \\ National University of Life and Environmental Sciences of Ukraine \\ 15 Heroiv Oborony str., Kyiv, Ukraine, 03041 \\ snezhkoolha@gmail.com \\ Viktor Voroshchuk \\ Department of Food Technologies Equipment \\ Ternopil Ivan Pul'uj National Technical University \\ 56 Ruska str., Ternopil, Ukraine, 46001 \\ voroschuk@gmail.com
}

\footnotetext{
Abstract

The quality of modern food products may be improved by adding bee pollen (PB) to the composition. The important stage of the process of improvement of an existent product or creation of new one is the optimization of the technology of bee pollen preparation, especially, comminution. The aim of the researches was to investigate the process of comminution and to optimize technological parameters for receiving high quality powder, used as a component of sour-milk beverages and other products. The study elucidates the influence of a series of factors on the size of particles and quality of bee pollen powder by technological and phytochemical properties. Using the visual method with modern optimal devices, it was established, that pollen can be comminuted to the particles size $120-8 \mathrm{mcm}$. The dispersity degree of received powder caused changes of the phytochemical activity and technological parameters of a product. The method of colorimetry determined that the content of flavonoids in pollen increases by $53 \%$ at communiting to particle sizes $15 \pm 5 \mathrm{mcm}$ and decreases at the higher dispersity.

The screen method determined the homogeneity of the material, processed by three types of comminutors and substantiated the use of a mill-pestle in the technology of bee pollen comminution as the most effective comminutor.

Using the plan of the complete factor experiment of the third kind, there were studied the surfaces of a response of the dependence of pollen powder homogeneity on the comminutor work intensity, mass and term of the material processing. Technological parameters of pollen comminution by a mill-pestle were optimized: working body speed $70-80 \mathrm{turn} / \mathrm{min}\left(\mathrm{min}^{-1}\right)$, processing duration -6 min, batch mass $-150 \mathrm{~g}$.

Keywords: bee pollen powder, bee pollen comminution, full-features experiment, phytochemical activity of bee pollen. 


\section{Introduction}

Apiproducts are often used for enriching milk products. (Pat. BG 111284, Pat. UA 37155 U), [1-3]. Bee pollen [4-6], that exceeds all widely known preparations [7] by the composition and so by possibilities of the influence on the human organism is especially valuable among them. The main feature of pollen is that it is not recommended to be used for food in non-processed state [8]. So, the study of the process of bee pollen comminution is urgent.

The aim of the researches was to study the process of comminution and to optimize technical parameters for receiving high quality powder, used as a component for sour-milk beverages and other products.

The following tasks were realized for attaining this aim:

- to study comminuted BP, using the microscopy method;

- to study phytochemical and technological properties of BP powder of different dispersity degrees;

- to realize the choice of a comminutor for BP dispersion;

to optimize parameters of BP comminution by the full-features experiment results.

\section{Materials and methods of the study of bee pollen comminution}

There were used the samples of polyflower BP, collected in Precarpathian region in 2014. BP humidity was not higher than $10 \%$, granule size $-3 \pm 1 \mathrm{~mm}$, color - yellow, tints of green and brown, smell- flower-honey, taste - sweetish.

The samples preparation provided BP drying in the layer $\leq 5 \mathrm{~mm}$ in convective stoves at the temperature $40 \pm 2{ }^{\circ} \mathrm{C}$ to $3 \pm 1 \%$ humidity, comminution using the ball, cutting, striking comminutors and mill-pestle. The last one was equipped by the cup for comminution with the maximal load $150 \mathrm{~g}$ of BP.

BP extraction on the water bath was prepared to determine the flavonoids content by the maceration of $20 \mathrm{~g}$ of powder of different dispersity degrees during 7 days. BP powder was added with $200 \mathrm{ml}$ of extragent at the temperature $15-20{ }^{\circ} \mathrm{C}$ and mixed 5 times/day.

Sizes of powder particles were determined by the method of microscopy [9]. The material preparation was the following: the dose of a pollen sample $(0,2 \pm 0,1 \mathrm{~g})$ was placed on the subject glass, added with 1-2 drops of distilled water, closed by the covering glass and looked under the microscope though the ocular $\times 10$ with the diameter of the field of view $18 \mathrm{~mm}$ and the lens $\times 40$.

BP powder homogeneity was determined by the screen method [10]. Powder was divided in different fractions by particles sizes, using the set of sieves of the laboratory screen shaker. The mass of BP powder batch was $100 \pm 0,5 \mathrm{~g}$, the pile of sieves was shaken during 15 minutes. Material, remained on each sieve, was eliminated weighted, and its mass share was determined (\%).

Friableness is the one of most spread trials for powder-like materials that means the speed of powder flow through the orifice under the force of its own weight. The testing was realized as following: $300 \pm 0,5$ of material were put without compression in the dry funnel, stably fixed on the support, with the closed orifice, then the orifice was opened and powder was thrown away during 10 seconds. The result was calculated as a mean value for all repeats of the experiment and expressed in $\mathrm{g} / \mathrm{s}$. The experiment was repeated fourfold for samples of the correspondent dispersity under analogous conditions and using the same container with the orifice.

A bulk mass - is a mass of one cubic centimeter of BP powder, freely put in an orifice. For determining it, BP powder was poured in the laboratory glass with the volume $200 \mathrm{ml}$ through the funnel, fixed in the support on the height $10 \mathrm{~cm}$ from the higher border of the glass. The excess of powder was cut by the rule at the edges level and weighed for determining the bulk mass. The obtained mean values of the results of three successive measurements were expressed in $\mathrm{g} / \mathrm{cm}^{3}$.

The friableness and bulk mass were determined according to ISO 4324:1977 Surface Active Agents - Powders and Granules - Measurement of the Angle of Repose.

Flavonoids were determined by the method of colorimetry using aluminium chlorine [11], that is grounded on $\mathrm{AlCl}_{3}$ ability to create acid-proof complexes with keto groups C-4 and C-3 or C-5 hydroxyl groups of flavons or flavonols. For determining the general content of flavonoids in BP sample extract, the standard calibrating curve was built on the base of quercetin solutions of different concentrations. For getting the output solution, $100 \mathrm{mg}$ of BP extract were mixed with $5 \mathrm{ml}$ of methanol 
and added with methanol to the volume $10 \mathrm{ml}$. Water solutions of aluminium chloride $-10 \%, 1 \mathrm{M}$ potassium acetate in $0,1 \mathrm{ml}$ and $1,5 \mathrm{ml}$ of methanol and $2,8 \mathrm{ml}$ of distilled water were put in the test tube with the output solution and in separate test tubes with quarcetin solutions of different concentrations and mixed up well. The control for all solutions of the standard quercetin and extraction with BP was prepared by the standard method, by replacing aluminium chloride by distilled water. All prepared solutions were filtered if necessary, and absorption was measured using the wave length $415 \mathrm{~nm}$.

The forms of the response surface were studied using the plan of the full-features experiment of the third kind $\left(\mathrm{FFE}^{3}\right)$ [12], in which result eight coefficients of regression were determined by the equation:

$$
\begin{aligned}
y= & b_{0}+b_{1} x_{1}+b_{2} x_{2}+b_{3} x_{3}+b_{12} x_{1} x_{2}+ \\
& +b_{13} x_{1} x_{3}+b_{23} x_{2} x_{3}+b_{123} x_{1} x_{2} x_{3},
\end{aligned}
$$

where $\mathrm{x}_{\mathrm{i}}$ - the reentrant variables, chosen as: processing term, min; batch mass, $\mathrm{g}$; speed of the comminutor's working body turning, turn/min; $\mathrm{y}$ - the output variable, chosen as homogeneity, $\%$.

The variation intervals of each factor correspondingly equal to: $\mathrm{I}_{1}=2 \mathrm{~min}$; $\mathrm{I}_{2}=50 \mathrm{~g}$; $\mathrm{I}_{3}=5$ turns $/ \mathrm{min}$.

The planning matrix (Table 1 ) provides that the graphs $\mathrm{x}_{1} \mathrm{x}_{2}, \mathrm{x}_{1} \mathrm{x}_{3}, \mathrm{x}_{2} \mathrm{x}_{3}$ and $\mathrm{x}_{1} \mathrm{x}_{2} \mathrm{x}_{3}$ have the auxiliary value for calculating the regression coefficients $b_{12}, b_{13}, b_{23}$.

\section{Table 1}

The experiment plan for FFE $2^{3}$ realization

\begin{tabular}{|c|c|c|c|c|c|c|c|c|c|c|c|}
\hline \multirow[t]{2}{*}{ No. } & \multicolumn{3}{|c|}{ variables } & \multicolumn{8}{|c|}{ codified } \\
\hline & $I_{1}$, turns $/ \mathrm{min}$ & $\mathbf{I}_{2}, \min$ & $\mathbf{I}_{3}, \mathrm{~g}$ & $\mathbf{X}_{0}$ & $X_{1}$ & $\mathbf{X}_{2}$ & $\mathbf{X}_{3}$ & $\mathbf{X}_{1} \mathbf{X}_{2}$ & $\mathbf{X}_{1} \mathbf{X}_{3}$ & $\mathbf{X}_{2} \mathbf{X}_{3}$ & $\mathbf{X}_{1} \mathbf{X}_{2} \mathbf{X}_{3}$ \\
\hline 1 & 70 & 2 & 50 & 1 & -1 & -1 & -1 & 1 & 1 & 1 & -1 \\
\hline 2 & 80 & 2 & 50 & 1 & 1 & -1 & -1 & -1 & -1 & 1 & 1 \\
\hline 3 & 70 & 6 & 50 & 1 & -1 & 1 & -1 & -1 & 1 & -1 & 1 \\
\hline 4 & 80 & 6 & 50 & 1 & 1 & 1 & -1 & 1 & -1 & -1 & -1 \\
\hline 5 & 70 & 2 & 150 & 1 & -1 & -1 & 1 & 1 & -1 & -1 & 1 \\
\hline 6 & 80 & 2 & 150 & 1 & 1 & -1 & 1 & -1 & 1 & -1 & -1 \\
\hline 7 & 70 & 6 & 150 & 1 & -1 & 1 & 1 & -1 & -1 & 1 & -1 \\
\hline 8 & 80 & 6 & 150 & 1 & 1 & 1 & 1 & 1 & 1 & 1 & 1 \\
\hline
\end{tabular}

\section{Factors changes}

The regression coefficients were calculated, using the mean actual values:

$$
\begin{gathered}
\mathrm{b}_{0}=\frac{\sum_{\mathrm{u}=1}^{\mathrm{N}=8} \overline{\mathrm{y}}_{\mathrm{u}}}{\mathrm{N}}, \\
\mathrm{b}_{1}=\frac{\sum_{\mathrm{u}=1}^{\mathrm{N}=8} \mathrm{x}_{\mathrm{iu}} \overline{\mathrm{y}}_{\mathrm{u}}}{\mathrm{N}} .
\end{gathered}
$$

For assessing the regression coefficients significance, the statistical analysis was realized and dispersion was determined. The adequacy of the equation was verified by Fisher calculation criterion. 
All researches were realized with three- fourfold repetition. The significance of differences was determined at $\mathrm{P} \leq 0,05$. The mathematical processing of the data, diagrams creation, mathematical modeling by the method of the full-featured experiment were realized using statistic, graphic, mathematical functions of Microsoft Excel 2010 program.

\section{Results}

Using the modern comminutors (Fig. 1) bee pollen can be comminuted to sizes, varied from 120 to $8 \mathrm{mcm}$ (Fig. 2).

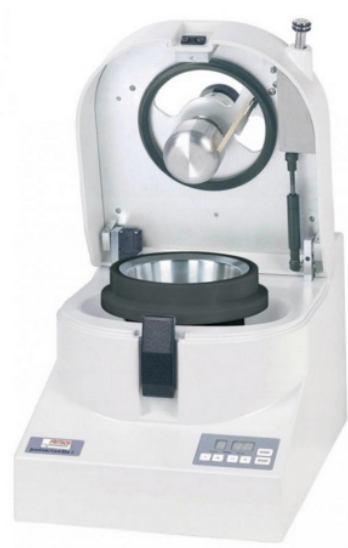

$a$

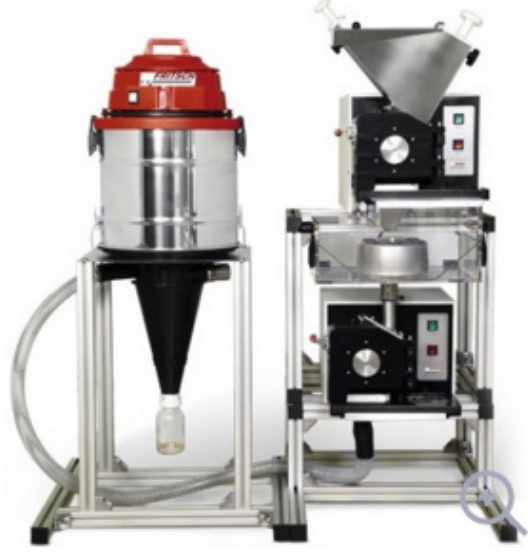

$c$

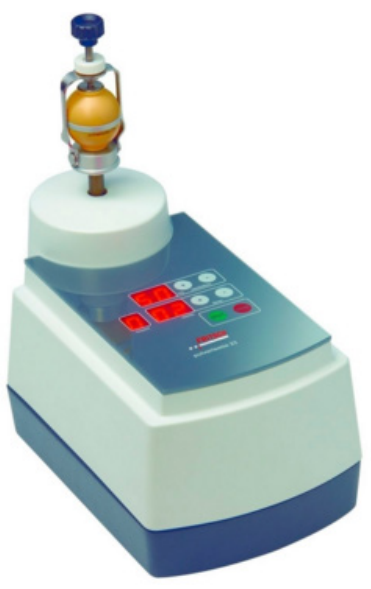

$b$

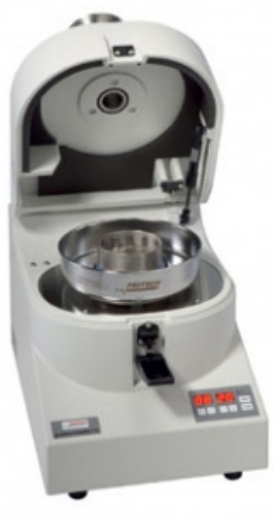

$d$

Fig. 1. Highly effective comminutors: $a$ - mill-pestle; $b$ - ball mill; $c$ - cutting comminutor; $d$ - striking comminutor

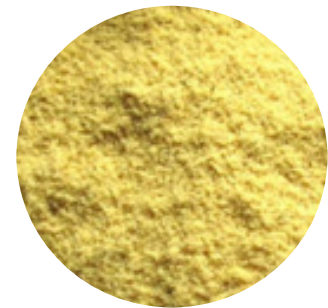

$a$

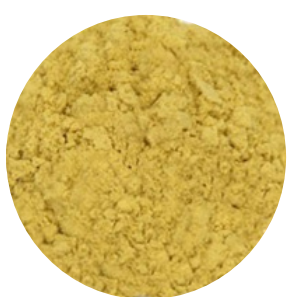

$b$

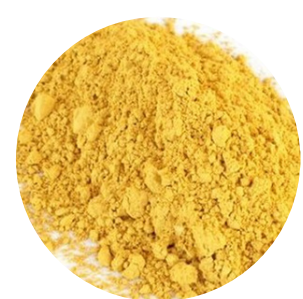

$c$

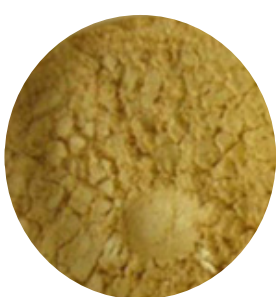

$d$

Fig. 2. Samples of bee pollen of different dispersity degreees: $a-115 \pm 5 \mathrm{mcm}$; $b-20 \pm 2 \mathrm{mcm} ; \mathrm{c}-15 \pm 2 \mathrm{mcm} ; \mathrm{d}-10 \pm 2 \mathrm{mcm}$

The increase of bee pollen powder dispersity causes phytochemical changes that lead to flavonoids content variations (Fig. 3). 


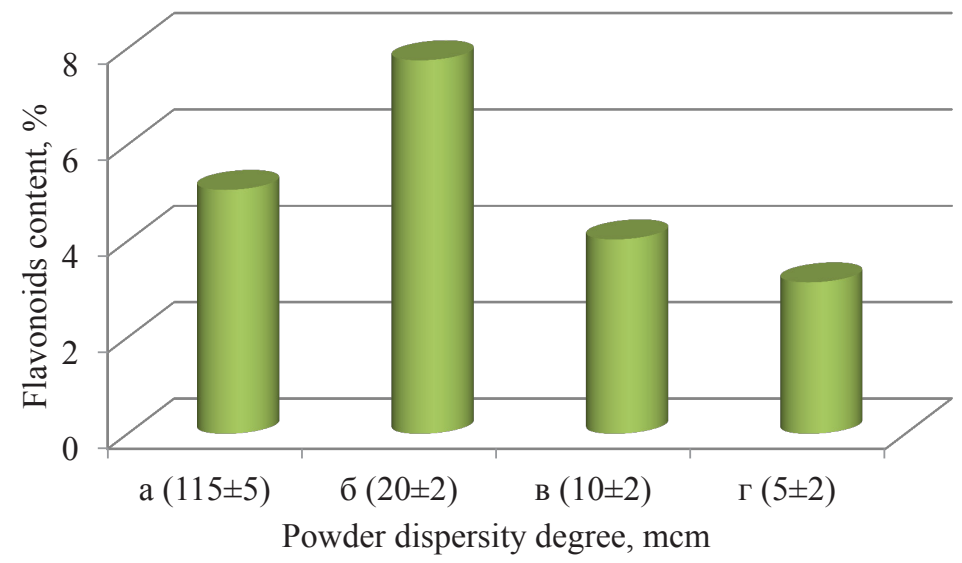

Fig. 3. The dispersion influence on the phytochemical ativity of comminuted bee pollen

BP samples with particle sizes $20 \pm 2$ mcm contained by $53 \%$ more flavonoids than ones with particle sizes $115 \pm 5 \mathrm{mcm}$ and by $52 \%$ - than ones with particle sizes $10 \pm 2 \mathrm{mcm}$. The further dispersity increase favors the gradual decrease of flavonoids.

Technological characteristics of pollen powder depend on the comminution degree in such a way that the bulk mass increases proportionally to the dispersity growth (Table 2). Alongside with it the extra-thin dispersion of bee pollen leads to friableness losses that, in its turn, can have negative results for the technology of manufacturing new products that contain bee pollen powder.

Table 2

Technological characteristics of bee pollen powder of the different dispersity degree, $n=5, p \leq 0,05$

\begin{tabular}{cccc}
\hline \multirow{2}{*}{ Powder group } & Dispersity, mom & \multicolumn{2}{c}{ Technological parameters of quality } \\
& $115 \pm 5$ & Bulk mass, $\mathbf{g} / \mathbf{c m}^{\mathbf{3}}$ & Friableness, $\mathbf{g} / \mathbf{s}$ \\
\hline 1 & $20 \pm 2$ & 0,56 & 1,04 \\
2 & $15 \pm 2$ & 0,59 & 2,9 \\
3 & $10 \pm 2$ & 0,62 & 2,8 \\
5 & $5 \pm 2$ & 0,62 & 1,5
\end{tabular}

The comminutor type, working body speed, comminution time, container infill degree are the most powerful factors of the comminuted product quality [13].

The comminutor was chosen, based on the results of the assessment of homogeneity and dispersity of the comminuted material (Fig. 4).

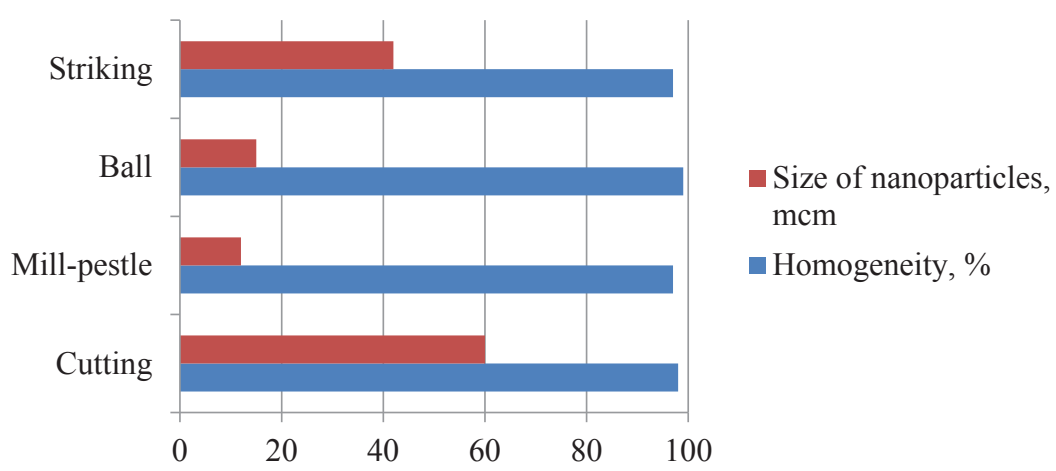

Fig. 4. The influence of the comminutor type of bee pollen quality 
The mathematical model, obtained by $\mathrm{FFE}^{3}$ testifies to the fact that the optimal technical parameters of the process of bee pollen comminution on the mill-pestle is the frequency of comminutor's the working body turning 70-80 turns $/ \mathrm{min}\left(\mathrm{min}^{-1}\right)$, processing duration $-6 \mathrm{~min}$, batch mass $150 \mathrm{~g}$. Under such conditions BP powder has the highest quality: homogeneity $-96 \pm 1 \%$, dispersity $-15 \pm 5 \mathrm{mcm}$.

\section{Conclusions}

At the correct choice of regimes and equipment, bee pollen has the ability to be comminuted to the particle sizes $120-8 \mathrm{mcm}$.

The mechanical processing influences the phytochemical activity of bee pollen, proved by the high content of flavonoids $(\geq 7 \%)$ in powder with the size $15 \pm 5 \mathrm{mcm}$ and the low $(3 \%)$ in powder with the size $\leq 5 \mathrm{mcm}$.

According to the results of bee pollen homogeneity and dispersity, there was substantiated the mill-pestle use in the technology of bee pollen comminution as the most effective comminutor.

The technological parameters of bee pollen comminution by the mill-pestle were optimized: working body speed 70-80 turns $/ \mathrm{min}\left(\mathrm{min}^{-1}\right)$, processing duration $-6 \mathrm{~min}$, batch mass $-150 \mathrm{~g}$.

The research results can be used for creating new products in the food, pharmaceutical, cosmetological branches and improving existent ones.

\section{References}

[1] Rashid, A., Thakur, Er. S. N. (2012). Studies on Quality Parameters of Set Yoghurt Prepared By the Addition of Honey. International Journal of Scientific and Research Publications, 2 (9), 1-10.

[2] Yerlikaya, O. (2014). Effect of bee pollen supplement on antimicrobial, chemical, rheological, sensorial properties and probiotic viability of fermented milk beverages. Mljekarstvo, 64 (4), 268-279. doi: $10.15567 / \mathrm{mljekarstvo.2014.0406}$

[3] Shleykin, A. G., Barakova, N. V., Petrova, M. N., Danilov, N. P., Argymbaeva, A. E. (2015). Vliyanie sakharnogo siropa, meda i zlakov na reologicheskie svoystva yogurta. Nauchnyy zhurnal NIU ITMO, 2, 24-34.

[4] Snezhko, O., Lomova, N., Narizhnyy, S., Mingaleeva, Z. S. (2015). Enhancing food safety of pollen by means of irradiation. Ukrainian Food Journal, 4 (1), 32-39.

[5] Snezhko, O. O., Lomova, N. N. (2014). Influence of incorporating honey, royal jelly and pollen on biotechnological processes of dairy drink. Eastern-European Journal of Enterprise Technologies, 2 (12 (68)), 62-65. Available at: http://journals.uran.ua/eejet/article/view/23359

[6] Lomova, M. N. (2015). The Biomass of Streptococcus thermophilus and Bifidobacterium longum in dairy medium with bee pollen. Biotechnologia Acta, 8 (1), 71-75. Available at: http://nbuv.gov.ua/ UJRN/biot_2015_8_1_10 doi: 10.15407/biotech8.01.071

[7] Solomka, V. A., Tyndyk, E. V. (2014). Tsvetochnaya pyl’tsa i zdorov'e. Kyiv: Meditsina Ukrainy, 14. Available at: http://dopomoha.kiev.ua/firms/med-pilca.htm

[8] Rimpler, M. (2003). Von Bienen gesammelte Blutenpollen: Eigenschaften und Verwendung. Arztezeitschrift für Naturheilverfahren, 44 (3), 158-165.

[9] Dodds, J., Bhandari, B., Bansal, N., Zhang, M., Schuck, P. (2013). Techniques to analyse particle size of food powders. Handbook of Food Powders, 309-338. doi: 10.1533/9780857098672.2.309

[10] Murthy, T. P. K., Manohar, B. (2013). Grinding Studies of Mango Ginger: Mathematical Modelling of Particle Size Distribution and Energy Consumption. American Journal of Food Science and Technology, 1 (4), 70-76.

[11] Pekal, A., Pyrzynska, K. (2014). Evaluation of Aluminium Complexation Reaction for Flavonoid Content Assay. Food Analytical Methods, 7 (9), 1776-1782. doi: 10.1007/s12161-014-9814-x

[12] Biyik, S., Aydin, M. (2015). The Effect of Milling Speed on Particle Size and Morphology of Cu25W Composite Powder. Acta Physica Polonica A, 127 (4), 1255-1260. doi: 10.12693/aphyspola.127.1255 